\title{
中国「新」時代に制作されたと伝えられる貨幣『一刀』に 用いられた金属工芸技法
}

\author{
桐野文良大野直志田口智子
}

東京藝術大学大学院

J. Japan Inst. Met. Mater. Vol. 83, No. 3 (2019), pp. 87-96

(C) 2019 The Japan Institute of Metals and Materials

\section{Metal Craft Production Techniques for an Ancient Chinese Coin Named Ittou Manufactured in the Shin Period of Ancient China}

Fumiyoshi Kirino, Naoshi Ohono and Satoko Taguchi

Graduate School, Tokyo University of the Arts, Tokyo 110-8714

The metal craft production techniques for an ancient Chinese coin named Ittou in the Shin period of ancient China were studied from material science viewpoints. This cultural artefact was manufactured in the Shin period of ancient China. An infrared image shows the surface state and the materials absorbed on the surface. According to infrared images of the cultural artefact, roughness on the surface of this coin was created on cooling during mintage. UV-fluorescence images show luminescence at corrosion products and yellow soil. In X-ray transmission images, some voids in this coin were observed, indicating the metal craft production technique used during this period. The main element of this cultural artefact is $\mathrm{Cu}$ and other elements are $\mathrm{Sn}$ and $\mathrm{Pb} . \mathrm{X}$-ray diffraction patterns indicate the presence of $\mathrm{Cu}-\mathrm{Sn}$ base intermetallic compounds. Ittou coins are made from bronze. The characters on the coins were formed using an inlay technique called zougan. Yellow soil adhered to the surface of the examined coin from where it was excavated. The material used to form the characters on the coin is 10 mass $\%$ $\mathrm{Cu}-\mathrm{Au}$ alloy, and flaws were observed on the surface of the characters. The compositions of ancient Kan coins produced between the east Kan and west Kan periods were also analyzed. The composition of these ancient coins was the same as that of the coin from the Shin period of old China, indicating that the same metal craft production technique was used in both periods. These techniques were improved in this period, enabling many coins to be manufactured. [doi:10.2320/jinstmet.J2018045]

(Received August 27, 2018; Accepted December 17, 2018; Published February 8, 2019)

Keywords: ancient Chinese coin, metal craft production technique, bronze, void, inlay technique

\section{1. 緒言}

大陸から我が国に伝わった金属工芸は日本独自の発展をと げ江戸時代後期に成熟期を迎える。工芸技法を用いて制作さ れたのが貨幣で，これには政府の威信もあり，高度な金属工 芸技法が用いられている，特に，金属貨幣に着目して制作技 法を調べることで当時の金属工芸技法の一端を知ることがで きる。わが国における貨幣の自然科学的および社会科学的な 視点からの研究は Ashidaの研究1)にはじまるとされる。こ れを踏まえて，これまでに著者らは金属学的な視点からわが 国の文化財資料である貨幣の和同開珎 ${ }^{2)}$ ，文政一朱金 ${ }^{3)}$ ，小 判4) を取り上げ，その制作技法や色揚げなどの金属工芸の彩 色技法について調べた結果を報告してきた。また，豊臣秀吉 が制作したと伝えられる貨幣型恩賞品(永楽通宝や天正通 宝 $)^{5)}$ および小判や銀判 ${ }^{6)}$ の内部応力の測定により金属工芸の 制作技法を推定し，得られた結果を踏まえて実験的にその技 法を復元した結果を報告した。これらの検討から，文化財資 料の研究は我が国の金属工芸の発展の推移の一部を垣間見る ことができる.

ところで，わが国の金属工芸の源流は大陸，すなわち中国 にある7 ${ }^{7,8}$ とされる. 金属工芸技法の適用の観点から古代中
国における初期の貨幣制作を金属工芸の視点から歴史的にみ る.中国で最初に制作された貨幣に用いられた材料は金属で はなく天然物の宝貝である。その後，時を経て金属貨幣の生 産が始まるのは春秋戦国時代中期ごろで，用いられた材料は 青銅である．形状は布銭 (鋤などの農具)や刀銭, 圓銭, 蟻鼻 銭をはじめ, 魚や楽器を模したものなどに始まり, やがて円 形の方孔銭へと移り変わっていく ${ }^{8-10)}$. 紀元前 206 年に成立 した漢王朝(中国では西漢, 日本では前漢とよばれ，都は西 安である)における貨幣の製造をみると，建国直後の王朝は 内乱の平定と匈奴との戦いが続き, 王朝として貨幣を発行し たのは紀元前 118 年の五銖銭からである。それまでは前王朝 である秦の半両銭を引き継ぐとともに，民間での鋳造を認め るなどの形を取らざるをえなかった ${ }^{8,9)}$. 建国当時は半両銭 が通用していたが，これがやがて 5 銖銭に改鋳されていく. その後, 西暦 9 年に漢の実権を握った王茾により新王朝をた て漢は一時途絶える. 王莽は精力的に貨幣を発行するととも に貨幣制度を見直している ${ }^{8-10)}$ 。その後, 西暦 25 年に漢 (中 国では東漢，日本では後漢とよばれ，都は洛陽である)が再 興され，再び五銖銭が製造され流通するようになる。ここ で，新の時代の 14 年間をみると，王莽は名目貨幣(貨幣重量 と貨幣価值が不一致) として多種多様の貨幣を発行 (王莽銭と もよばれる)している ${ }^{8-10)}$. そのはじめが漢時代の五銖銭を 
廃止し同額面の小銭直一の制作(西暦 9 年)であり, これを貨 泉(西暦 14 年)に改鋳している。この間に王莽は国内すべて の金を国有化する経済政策を実行している。王莽の政策は名 目貨幣ゆえに私鋳，盗鋳が多発したり，貨幣制度そのものが 複雑化したりするなどの経済的な弊害を招くことにな $ろ^{8-10)}$. このような経済的社会的な背景を踏まえ, 王莽が精 力的に発行した新の時代の貨幣を取り上げることはこの時代 の金属工芸における制作技法 (以下, 金属工芸技法と記載す る)を知る上で興味深い.

そこで, 本研究では新王朝において王艻が精力的に制作し た貨幣のうち金象嵌が用いられたと伝えられる『一刀』とよば れる貨幣を研究対象の文化財資料として取り上げる。この 『一刀』は小泉直一の 5000 枚分の価值があるとされる最も高 額な貨幣として制作された，先にも述べたように貨幣はその 国の高い金属工芸技法が使われたとされ，その技法を調べる ことは意義深い.これにより，王莽の時代の鋳造技術をはじ めとする漢王朝の金属工芸技法の一端を明らかにすることが できる，得られた結果をこれまでに報告したわが国における 貨幣の制作技法と比較することで金属工芸技法の歴史的な流 れを知ることができる. 本研究の目的は新の時代に制作され た『一刀』を中心に，その前後の時代の漢王朝が制作した貨幣 を文化財資料としてとりあげ，系統的に調べることにより貨 幣の制作技法の変遷の特徵を金属工芸技法の視点から概観 し，王莽の時代の鋳造を中心とする金属工芸技法の一端を明 らかにすることである.

\section{2. 研 究方 法}

\section{1 本研究で用いた文化財資料}

本研究で文化財資料として取り上げる『一刀』(桐野所蔵)の 外観像ならびに各所のサイズをまとめて Fig. 1 に示す。現存 する『一刀』の多くは，刀の柄の部分にこの貨幣が附属した形 状で，小泉直一換算で 5000 枚に相当する高額貨幣として用 いられた ${ }^{8-10)}$ 。本研究で用いる文化財資料の『一刀』は真中に 方形の穴を有する円形の貨幣である。この文化財資料は直径 が $28.5 \mathrm{~mm}$ の円形で, 中心に内側の長さが $7.6 \mathrm{~mm}$ の角穴で ある.また，この資料には縁が資料の外側と方向穴の周囲に 形成されている．表面及び断面の模式図で示す各所のサイズ を測定した。外周部部分の周囲は表が $1.2 \mathrm{~mm}$ 高さ, 裏が $0.9 \mathrm{~mm}$ 高さの縁が，また，各穴部分の周囲には $0.8 \mathrm{~mm}$ 高さ の縁がそれぞれ形成されている．縁以外の平坦な部分の厚さ は約 $1.1 \mathrm{~mm}$ である. 一方の面に「一刀」という黄色の文字が 中心の角穴を挟んで書かれている。この文字は金象嵌という 金属工芸技法により制作されたと伝えられている。資料の両 面ともに錆が生じ，文字が書かれていない面の周辺部分に黄 土色の土状の物質が付着している。 このことから，この資料 は出土品と考えられる. 制作地は中国で, 制作年代は「新」の 王莽の時代(西暦 7 年) と伝えられている ${ }^{8-10)}$.

さらに，漢王朝の初めである西漢から，一刀が制作された 新を経て, その後の東漢 (後漢)の初めまでの同一地域で制作 された 12 種類で 14 個の文化財資料の組成や鋳造技術を調

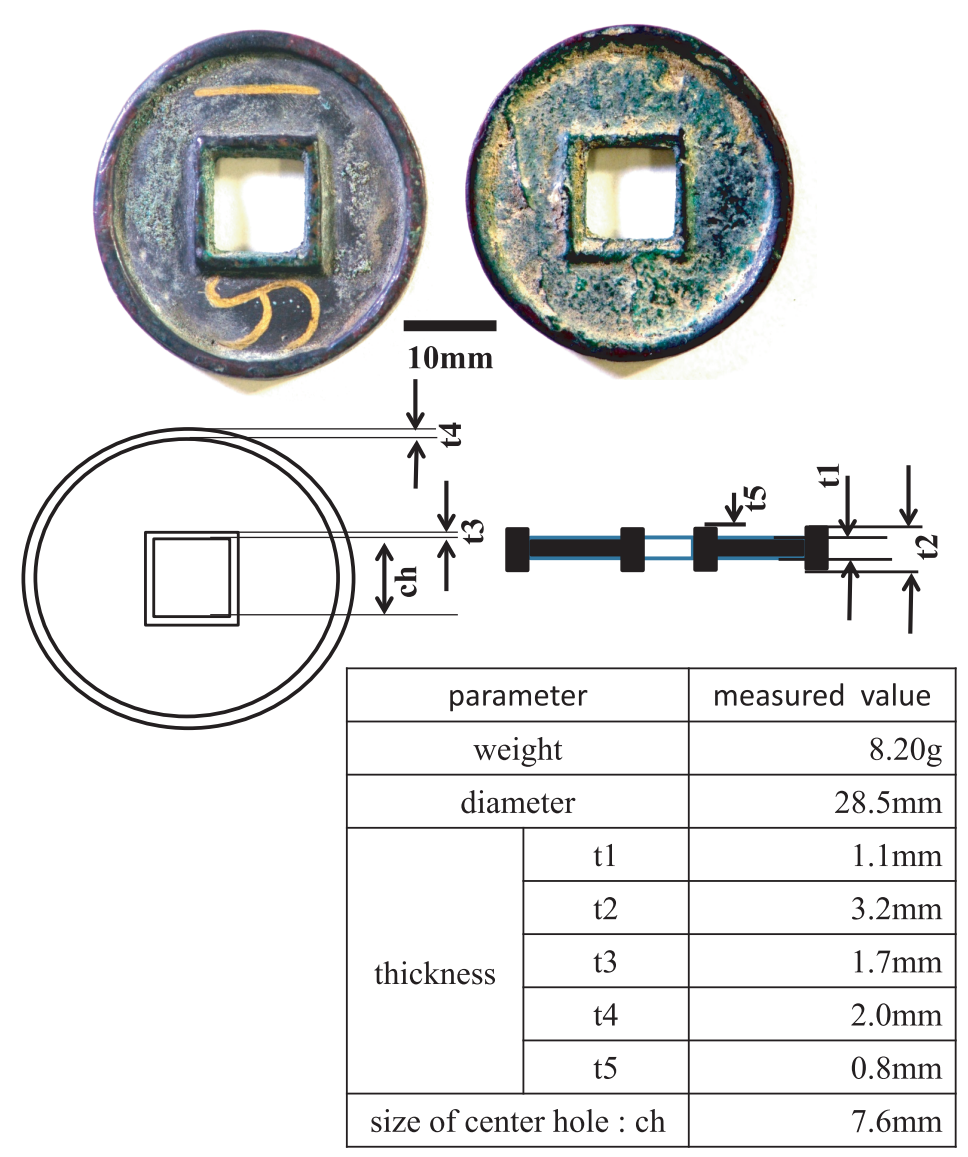

Fig. 1 Images of studied cultural properties of "Ittou" ancient old coin (owned by F. Kirino). 
ベ，一刀と比較した．用いた文化財資料(いずれも桐野所蔵) の外観像を Fig. 2 に示す．表面の状態から，いずれの文化財 資料ともに出土銭である。西漢の時代の資料の中で，半両銭 各種は秦の時代から継続して制作された銭貨であり, 漢王朝 が自ら製造したのは小五銖銭以降の貨幣である．また，複数 の同一種の文化財資料は組成などのバラツキを検討するため である.この中で, 提灯半両は制作年代が不明で, 布泉は文 献に制作の記載がなく出土した層序から年代を推定する考古 学的手法により決定された年代を用いた。 これらの文化財資 料と比較すると, 『一刀』の文字が異種の材料で制作されてい るようにみえるのが特徵の一つである.

\section{2 実験方法}

本研究では, (1)文化財資料の外観像の観察(紫外光や赤外 光, 可視光を用いた光学調査), (2)文化財資料の内部構造の 観察, (3)文化財資料に用いられた材料の元素ならびにその組 成, (4)材料の結晶構造, の 4 点について調べた。これらの結 果を総合して文化財資料の金属工芸技法を検討した。

(1) 外観像の観察 : 外観像の観察は可視光像, 紫外線蛍 光像ならびに赤外線像を撮影し, 得られた像を解析した. 紫 外線蛍光像の撮影は，暗室内でおこなった．波長が $365 \mathrm{~nm}$ および $254 \mathrm{~nm}$ の光を文化財資料に照射し，380 nm 以下の波 長の光を遮断するフィルター (Hmc-UV wp （株)ケンコー・ トキナー製)を介してデジタルカメラ(Cyber-shot DSC-R960,
$\operatorname{SONY}($ 株) 製)で撮影した。露光時間は $30 \mathrm{~s}$ である。この場 合, カメラに入射してくる光は可視光で, この波長領域に蛍 光を発する物質の存在を知ることができる. また, 赤外線像 は赤外線領域に感度を有する CCD を用いたカメラ (Cybershot DSC-R960, night shot mode, SONY(株)製)を使用し, $640 \mathrm{~nm}$ より短い波長の光を遮断するフィルター (R-64（株) ケンコー・トキナー製)を介して撮影した．赤外光源には夕 ングステンランプを用いた. 赤外線は侵入深度が深いので, 文化財資料表面の腐食層や污れなどを介して文化財資料自身 の表面の状態を見てとれるとともに，定性的ではあるが表面 の凹凸の状態を知ることができる。

各部位の詳細は画像処理機能付デジタル顕微鏡ならびに光 学顕微鏡, 走査型電子顕微鏡 $(\mathrm{SEM}, \mathrm{S}-2460 \mathrm{~N}$, (株) 日立製 作所製) および低加速電圧高分解能走査型電子顕微鏡 $(\mathrm{FE}-$ SEM，S-8010，（株) 日立ハイテクノロジーズ製)により観察 した.

（2）材料の組成分析：走査型電子顕微鏡 (S-2460N, （株） 日立製作所製）に附属するエネルギー分散型 X 線分析計 (EMAX, (株)堀場製作所製)により, 用いられた文化財資料 の元素ならびに組成を分析した. 分析対象は文化財資料の地 金部分と腐食層, 文字部(象嵌部分), 付着物などである.

（3）分光反射率の測定 : 画像色彩計 (ICA-2000, 浅枝設 計事務所製) に付属する分光ユニットを用いて，400〜 700 nm の波長範囲の分光反射率を測定した. 分光反射率の標準は硫

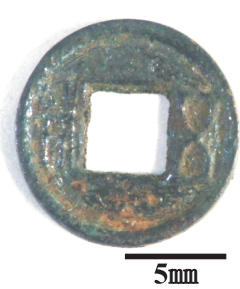

(A) Shou 5-shu

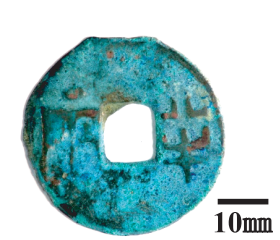

(E) 8-shu hanryou

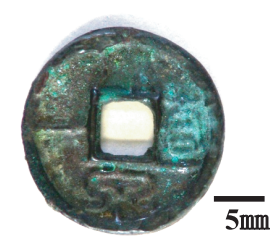

(H) Shousen chokuichi

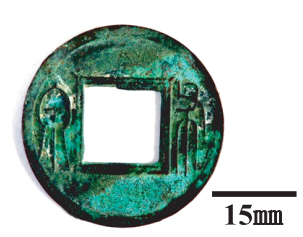

(K) Fusen

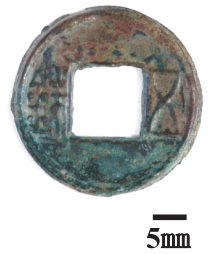

(B) $5-\operatorname{shu}$

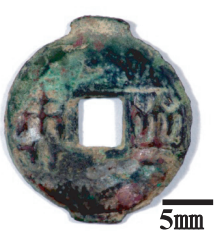

(F) Chouchin hanryou

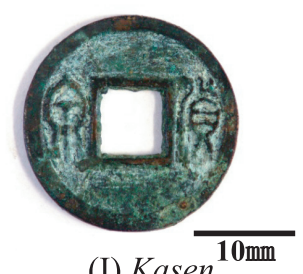

(I) Kasen

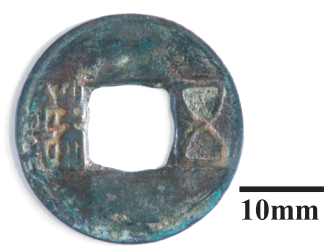

(L) Toukan 5-shu

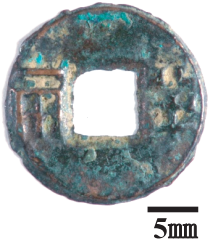

(C) 4-shu hanryou

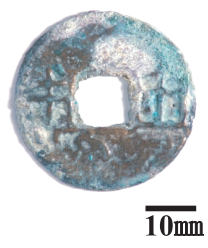

(D) 6-shu hanryou

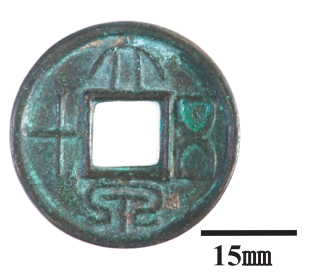

(G) Taisen 50

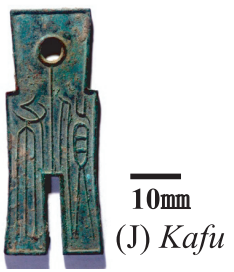

Fig. 2 Images of studied cultural properties of ancient Kan's coins (owned by F. Kirino). 
酸バリウムを $100 \%$ とした。

（4）結晶構造の解析：X線回折法により文化財資料の結 晶構造を調べ, 用いられた材料を同定した. あわせて表面の 腐食層を調べた。そのために, X 線回折装置 $(\mathrm{RINT}-$ ULTIMAIII およびRINT-RAPID，（株）リガク製）を用いた. 低角入射 $\mathrm{X}$ 線回折では管球が $\mathrm{Cu}$, 加速電圧が $40 \mathrm{kV}$ で, フィラメント電流は $50 \mathrm{~mA}, \mathrm{X}$ 線の入射角は $0.5^{\circ}$ で一定とし た。また，微小部 $\mathrm{X}$ 線回折では管球が $\mathrm{Cu}$ あるいは $\mathrm{Cr}$, 加 速電圧が $40 \mathrm{kV}$ でフィラメン電流が $30 \mathrm{~mA}, \mathrm{X}$ 線のビーム 径が $50 \mu \mathrm{m}$ である。

（5） X 線透過像および X 線 CT 画像の撮影：文化財資料 の内部構造を調べるために, X 線透過像ならびに X 線 CT 画 像を撮影した， X 線透過像は W をターゲットとする管球 ( $\mathrm{GE}$ 製) にイメージングプレート (GE 製)を組み合わせて撮 影した，撮影条件は管電圧が $150 \mathrm{kV}$, 管電流が $3 \mathrm{~mA}$ で照射 時間が $10 \mathrm{~s}$ である。また, X 線 CT 像の撮影には $3 \mathrm{D}$ マイク ロ X 線 CT (CT Lab (株)リガク製) 装置を使用した。撮影条 件は管電圧が $90 \mathrm{kV}$ ，管電流が $100 \mu \mathrm{A}$ である.

\section{3. 実験結果および考察}

\section{$3.1 『$ 一刀』の制作技法}

\subsection{1 光学調査}

文化財資料の光学調査として, 紫外線蛍光像および赤外線 像を撮影した，得られた結果を Fig. 3 に示す。まず，Fig. 3 (A)で示す紫外線蛍光像は, $365 \mathrm{~nm}$ と $254 \mathrm{~nm}$ の 2 種類の波 長の紫外線を文化財資料に照射したときの可視光領域の発光 をみる. 波長が $365 \mathrm{~nm}$ では文字面及び裏面ともに資料に付 着している土状物質から弱い蛍光がみられる。 また, 波長が $254 \mathrm{~nm}$ の場合は, 土状物質からの弱い蛍光に加えて, 文字 面の方孔の周囲を中心に強い蛍光がみられる。この部分を拡 大した可視光像 (A-5) と対比させると, この蛍光を発光して いる部分は腐食によって生じたと考えられる析出物が発光し ている，しかし，この発光は文字面のみで，腐食が文字面よ り著しい裏面での発光は見られない.このことは生成してい る腐食生成物が異なっていることを示唆している.

次に, 文化財資料の赤外線像を Fig. 3(B)に示す. ここで, 可視光を遮る物質が資料表面に層状に存在していると表面の 状態を知ることは困難である．赤外線はこの層を透過するの で，文化財資料の表面状態を観察することができる. Fig. 3 (B-1) は『一刀』の文字面, 同図 (B-2) は文字面の背面の赤外 線像である. 文字面と背面を比較すると, 文字面の方がその 背面より表面が平坦であることがわかる，貨幣は鋳造により 製造していることから，背面の凹凸はその形状から腐食によ り生成したものではなく, 貨幣の制作時に生成したと考えら れる.これは貨幣の制作当時の鋳型の制作技術や鋳造技術な どの金属工芸技法の水準の一部を示している．この点は Fig. 1 で示した可視光像からは凹凸の形状は明確に読み取ること はできない，また，可視光像で見られた腐食層と考えられる 緑色の生成物および背面の黄色の物質の一部は赤外線像では 観察されない.このように, 赤外線像の撮影により表面の凹 凸などの状態も強調されるので, 制作時の表面状態の推定や

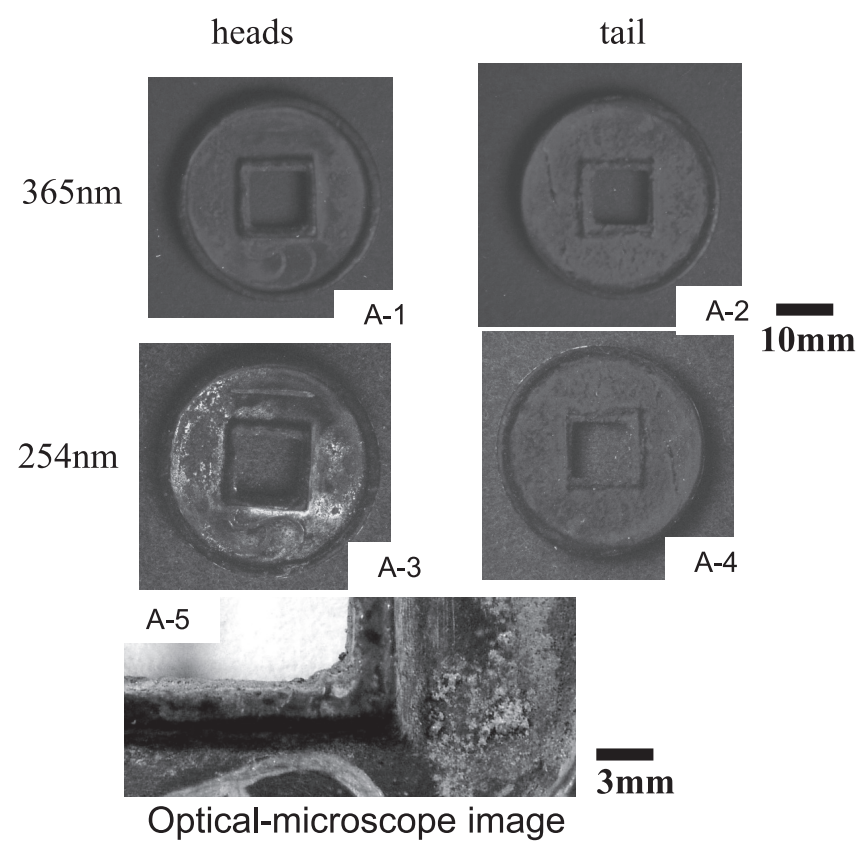

(A) UV-fluorescence images

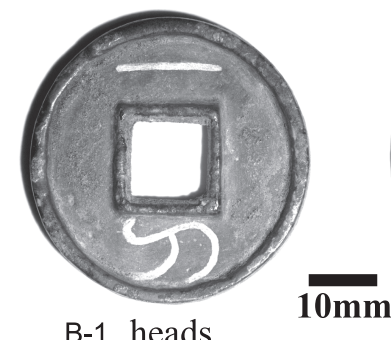

B-1 heads
$10 \mathrm{~mm}$

(B) Infrared images
Fig. 3 UV-fluorescence images and infrared images of "Ittou" ancient old coin.

腐食状況などを知ることができる.

\subsection{2 構成元素および組成}

文化財資料の構成元素および組成を走査型電子顕微鏡に付 属するエネルギー分散型 X 線分析計 (SEM-EDS, EMAX (株)堀場製作所製)により調べた。場所を変えて 5 箇所を SEM-EDS 法により測定し，得られた結果を平均した。 Table 1 は文字面の左右の金属部分の組成值である。これによる と，この貨幣の主成分は $\mathrm{Cu}$ ，これに 5〜 6 mass\%の $\mathrm{Sn}$ と $\mathrm{Pb}$ を含む青銅である．微量元素として As および $\mathrm{Ag}$ が検出さ れる.これらの元素は $\mathrm{Cu}$ 鉱石に含まれる不純物と推定され る.また, $\mathrm{Si}, \mathrm{Mg}, \mathrm{Al}$ は資料に付着している土壤の成分で あり，この文化財資料が出土品であることを示している。ま た, $\mathrm{S}$ と $\mathrm{Cl}$ は金属の腐食生成物を形成していると推定され る.ここで, $\mathrm{Fe}$ は文化財資料の地金成分か, 土猿成分に由 来するかはこの結果からは断定できない．地金成分であると すると，鋳型成分の混入か原料由来などの原因が考えられ る。

\subsubsection{X 線回折像}

文化財資料の結晶構造を低角入射 $X$ 線回折法(入射角度 : $\left.0.5^{\circ}\right)$ にり調べた. 文化財資料の表裏の回折プロファイル を Fig. 4 に示す. Fig. 4(A) が文字面, 同 (B) が背面である. 
Table 1 Composition of metal area on "Ittou" ancient coin.

$\operatorname{mass} \%$

\begin{tabular}{|c|c|c|c|c|c|c|c|c|c|c|c|}
\hline elements & $\mathrm{Cu}$ & $\mathrm{Si}$ & $\mathrm{Mg}$ & $\mathrm{Pb}$ & $\mathrm{Sn}$ & $\mathrm{S}$ & $\mathrm{Fe}$ & $\mathrm{Cl}$ & $\mathrm{Al}$ & $\mathrm{As}$ & $\mathrm{Ag}$ \\
\hline composition & 59.0 & 11.0 & 7.1 & 6.1 & 5.3 & 3.1 & 2.7 & 2.6 & 1.5 & 0.9 & 0.7 \\
\hline
\end{tabular}

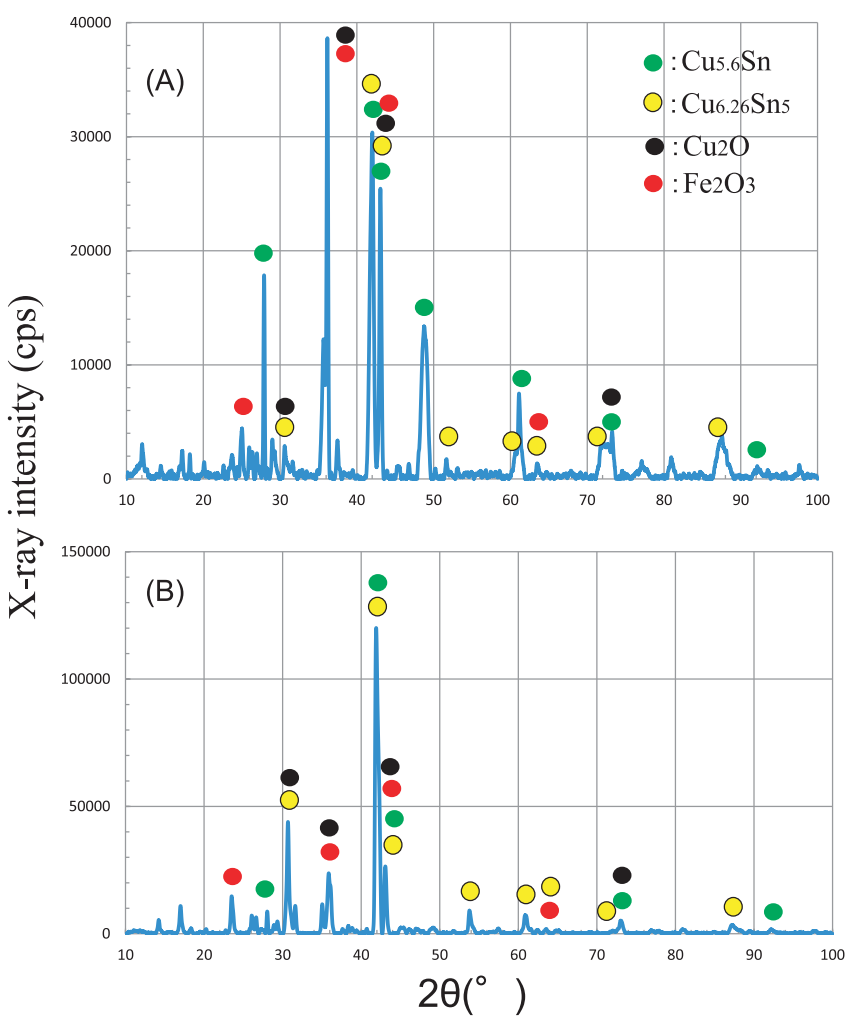

Fig. 4 X-ray diffraction patterns of "Ittou" ancient old coin.

Fig. 4(A) で示す文字面は文字の『一刀』にかからない部分の プロファイルである. Table 1 で示す元素情報をもとに Fig. 4 (A)で示すプロファイルのピークを同定した。 それによる と, Fig. 4(A)の文字面は $\mathrm{Cu}_{5.6} \mathrm{Sn}$ および $\mathrm{Cu}_{6.26} \mathrm{Sn}_{5}$ などの $\mathrm{Cu}^{-}$ $\mathrm{Sn}$ 系の金属間化合物が検出され，この他に $\mathrm{Fe}_{2} \mathrm{O}_{3}$ および $\mathrm{Cu}_{2} \mathrm{O}$ などの酸化物が検出される。 また, Fig. 4(B)の裏面は ピーク強度が表面より強くなるとともに, ピーク強度比など 配向性などに違いはみられるが, 検出される金属間化合物や 酸化物などに違いは見られない. Fig. 1 で示すようにこの資 料の厚さは $1.1 \mathrm{~mm}$ であるが, ピーク強度やその比が変化す るのは凝固の過程で厚さ方向に結晶成長していることを反映 しているのかもしれない。放であれば，冷却速度も結晶が ある程度成長できる速度であることが考えられる。あるいは 文字等を制作するときに熱処理した可能性などもある.

\subsubsection{X 線透過像}

文化財資料の内部構造を調べるためにX 線透過像を撮影 した。得られた像を Fig. 5 に示す。まず，図中に矢印で示し た像コントラストが暗いのはX X 線がほかの部分より透過し やすいことを示している．この部分は鋳造時に生成した鬆 （す）であると考えられる，矢印は代表位置で，この文化財資 料のほほ全面にわたり大小様々なサイズの鬆の生成がみられ る。また，図中に○で囲った部分も弱いが像コントラストが

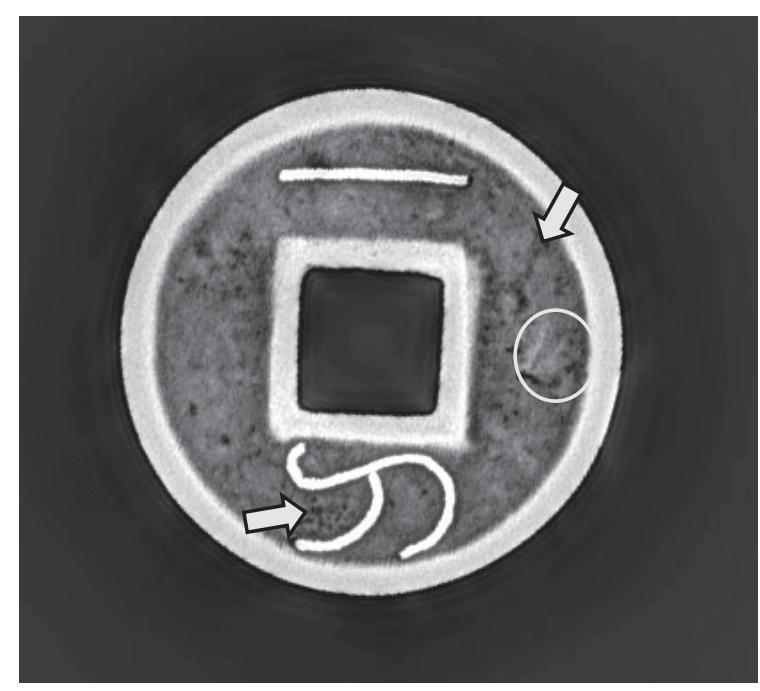

$150 \mathrm{kV} 3.0 \mathrm{~mA} 10 \mathrm{~s}$

Fig. 5 X-ray transmittance image of "Ittou" ancient old coin.

みられる.これは Fig. 3(B)で示す赤外線像と対比させると, 文化財資料の表面に緩やかな凹凸が生成していることに対応 している，これは厚さが不均一であることを示し，当時の鋳 造技術が十分に発達していないことを示唆している．この点 については，異なる時代であるが既報の日本の和同開珎 (青 銅銭)や貨幣型恩賞品である『永楽通宝』(銀製)における結 果 ${ }^{2,5}$ と同様で，鋳造技法が用いられた初期の特徴である.

次に，『一刀』の中の文字部に着目する。 まず，文字部の形 状をみると, 『刀』の字の曲線部分が滑らかに描かれていな い.さらに，『一』の字の部分も直線あるいは曲線になってい ない.これが制作当時の彫金の技術水準を示している。ま た，文字部分は像コントラストが最も明るいことから地金部 分よりもX線が透過しにくい材料が用いられていることを 示している，文字部分については，次節でさらに詳しく検討 する.

\section{2 文字部の制作技法}

\subsection{1 光学顕微鏡観察}

文化財資料の「一刀」の文字部分を光学顕微鏡で観察し，そ の代表的な 2 か所の像を Fig. 6 に示す. Fig. 6 で示すように 文字部分の表面は全面に多くの傷がみられる，傷の下から地 金は観察されないことから，この文字部は箔のような薄い材 料を地金に貼ったのではなく，䇴よりは厚い形状の材料が貼 られているか嵌め込まれて(象嵌されている)ようにみえる. また，地金と文字部の境界を見ると，隙間なく密着してい る. 文字部の表面にも土壤成分とみられる付着物が散在して いる. 


\subsection{2 構成元素および組成}

この資料の「一刀」の文字部分に用いられた材料を SEMEDS により調べた。得られた結果を Table 2 に示す。文字の 部分は $\mathrm{Au}$ と $\mathrm{Cu}$ との合金が主成分である. $\mathrm{Au}$ が 80 mass\% 以上含む合金であるので, Fig. 5 で示す X 線透過像において $\mathrm{X}$ 線が透過しにくいこととも一致する。また， $\mathrm{Si} ， \mathrm{Al}, \mathrm{Mg}$, $\mathrm{K}$ は先の光学顕微鏡観察で観察された土壤成分と考えられ る. 比較のために, 土壤が付着した部分の分析例を Table 3 に示す。これは埋蔵文化財であることを示している。この他 の $\mathrm{As}$ は $\mathrm{Cu}$ の不純物, $\mathrm{Cl}$ は環境中より侵入した $\mathrm{Cu}$ の腐食

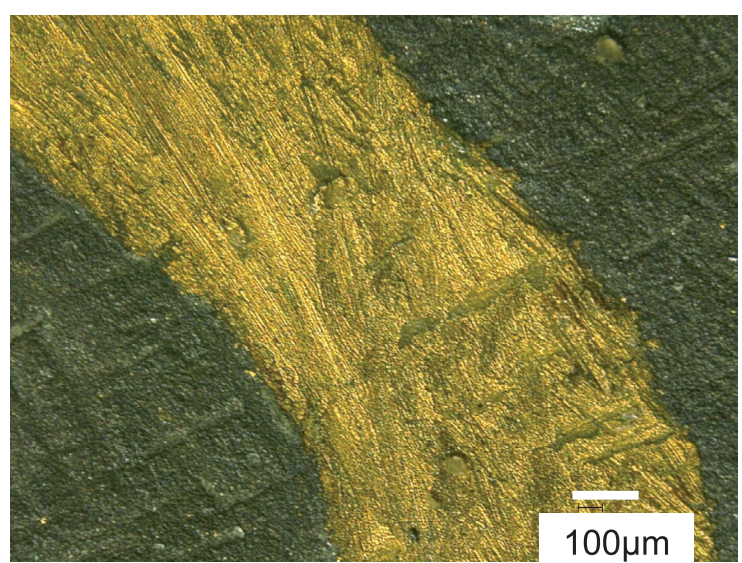

(A) Optical microscope image of letter area on Ittou ancient coin

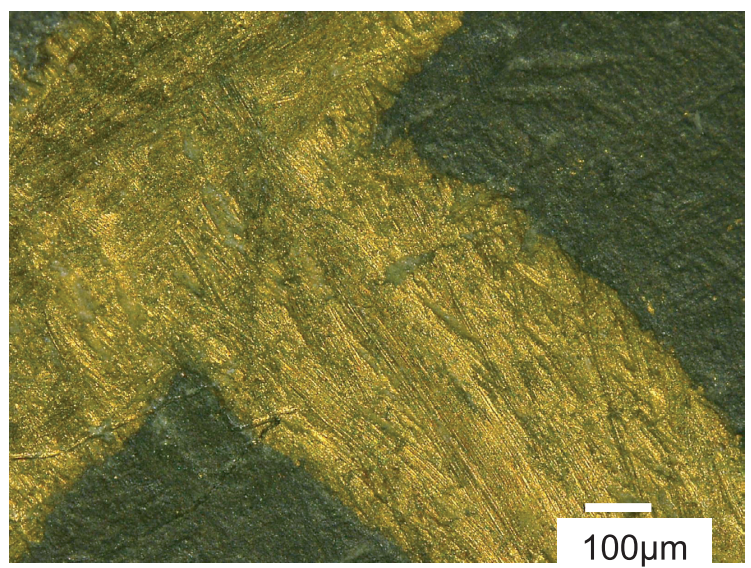

(B) Optical microscope image of letter area on Ittou ancient coin

Fig. 6 Optical microscope image of letter area on Ittou ancient old coin.
生成物に起因すると推定される.

\subsubsection{X 線回折像}

文化財資料の文字部の X 線回折像を測定し, 得られた結 果を Fig. 7 に示す.この図は, 文字の部分を中心にその周囲 および厚さ方向 $(X$ 線の侵入深さ) も含む領域の回折像であ る. Fig. 5 で示した $\mathrm{Cu}^{-} \mathrm{Sn}$ 系の金属間化合物ならびに金属酸 化物を除くと, $\mathrm{Au}-\mathrm{Cu}$ 系の金属間化合物の単独の回折ピー クが得られる. $\mathrm{Au}$ と $\mathrm{Cu}$ は平衡状態図的には規則格子変態 (固相変態)を有する全率固溶型 ${ }^{11}$ にに属する．合金の冷却時

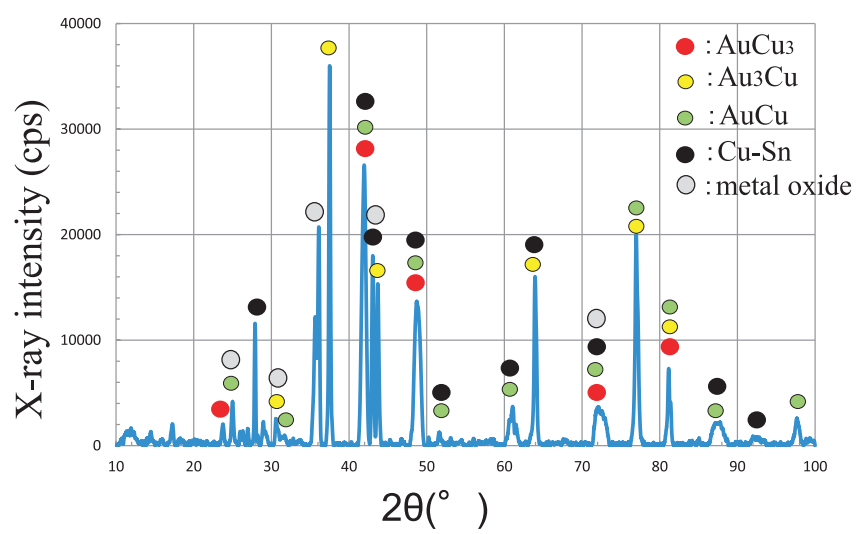

Fig. $7 \mathrm{X}$-ray diffraction patterns of the letter area on "Ittou" ancient old coin.

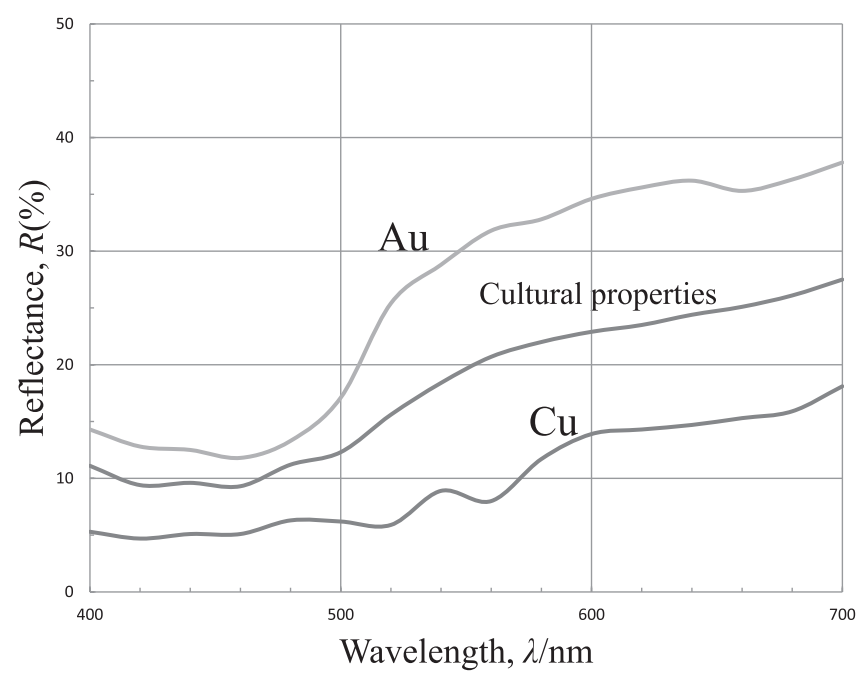

Fig. 8 UV visible reflective spectrum for the letter area on "Ittou" ancient old coin.

Table 2 Composition letter area on "Ittou" ancient coin.

\begin{tabular}{|c|r|r|r|r|r|r|r|r|r|}
\hline elements & \multicolumn{1}{|c|}{$\mathrm{Au}$} & $\mathrm{Cu}$ & $\mathrm{Fe}$ & $\mathrm{Al}$ & $\mathrm{Mg}$ & $\mathrm{Cl}$ & $\mathrm{Ca}$ & $\mathrm{As}$ & $\mathrm{Si}$ \\
\hline composition & 82.6 & 12.2 & 0.5 & 0.8 & 0.8 & 1.1 & 0.3 & 0.6 & 1.1 \\
\hline
\end{tabular}

Table 3 Composition of brown sand on "Ittou" ancient coin.

\begin{tabular}{|c|c|c|c|c|c|c|c|c|c|c|c|c|}
\hline elements & $\mathrm{Cu}$ & $\mathrm{Si}$ & $\mathrm{Mg}$ & $\mathrm{Pb}$ & $\mathrm{Al}$ & $\mathrm{Fe}$ & $\mathrm{Cl}$ & $\mathrm{S}$ & $\mathrm{Sn}$ & $\mathrm{K}$ & $\mathrm{Ca}$ & $\mathrm{Ag}$ \\
\hline composition & 50.8 & 19.4 & 9.4 & 5.8 & 4.6 & 2.4 & 2.0 & 1.9 & 1.7 & 0.8 & 0.6 & 0.6 \\
\hline
\end{tabular}


あるいは制作時に何らかの熱処理がなされた可能性がある.

\subsection{4 文字部の分光反射率}

文化財資料の文字部分の分光反射率を測定した．得られた 結果を Fig. 8 に示す. 比較のために, ここでは純 $\mathrm{Au}$ および 純 $\mathrm{Cu}$ の分光反射率をあわせて示す。比較資料の純 $\mathrm{Cu}$ は $590 \mathrm{~nm}$ に，そして，純 $\mathrm{Au}$ は $520 \mathrm{~nm}$ に吸収端がそれぞれ観 測される。この他に, 純 $\mathrm{Cu}$ は弱いが酸化物に起因する吸収 端も観測される。これに対して, 文化財資料の文字部の分光 反射率は $540 \mathrm{~nm}$ 付近に吸収端が観測され, 純 $\mathrm{Cu}$ と純 $\mathrm{Au}$ の 間である. $\mathrm{Au}-\mathrm{Cu}$ 系は合金平衡状態図的には規則格子変態 を有する全率固溶型 ${ }^{11)}$ に属するので, $\mathrm{Au}$ と $\mathrm{Cu}$ は任意の濃 度で均一に混合している。 上述の X 線回折プロファイルか ら $\mathrm{Au}$ と $\mathrm{Cu}$ は金属間化合物を形成しており，その化合物の 分光反射率は不明である。 ここでは, $\mathrm{Au}$ と $\mathrm{Cu}$ の混合と考 え, Table 2 で示す $\mathrm{Au}$ と $\mathrm{Cu}$ の濃度比 $(4: 1)$ を考慮すると, $\mathrm{Au}-\mathrm{Cu}$ 系分光反射率は純 $\mathrm{Cu}$ のスペクトルと純 $\mathrm{Au}$ のスペク トルとの濃度比に対応した加算で求めることができる。 それ によると, 吸収端は $540 \mathrm{~nm}$ 付近となり文化財資料の測定值 と一致する。

\subsection{5 文字部の $\mathrm{Au}$ 合金像の厚さの推定}

（1） SEM-EDS 法：SEM-EDS において, 加速電圧を増加 させて測定していくと電子線の侵入深さが増し, $\mathrm{Au}$ 合金の 厚さ方向の情報が得られる. 得られた結果を Fig. 9 に示す. この図から, 加速電圧が高くなるとともに, $\mathrm{Au}$ 濃度が僅か に増大する。これは加速電圧が高くなるとともに, 電子線の 侵入深度が増し表面に存在する土壌成分などの影響が小さく なったことに起因すると考えられる. そして, 加速電圧が $22 \mathrm{kV}$ 以上では $\mathrm{Au}$ 濃度はほほ一定になる。 今回の SEM-

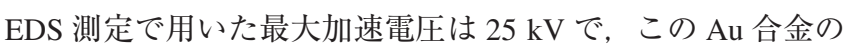
電子線の侵入深さをモンテカルロ法による計算機シミュレー ションで推定すると約 $0.5 \mu \mathrm{m}$ である. この深さ以上には電 子線は侵入できない。この結果から, 文字部を形成する $\mathrm{Au}^{-}$ $\mathrm{Cu}$ 層は少なくとも $0.5 \mu \mathrm{m}$ 以上となるが, Fig. 5 で示す X 線 透過像の像コントラストや Fig. 6 で示す光学顕微鏡観察結果 と比較すると, この厚さとは一致しない.これより $\mathrm{Au}$ 合金 層が厚いと, この手法での厚さ測定の限界となる。 そこで, $\mathrm{X}$ 線 CT 像撮影によりさらに詳細に内部構造等を調べた.

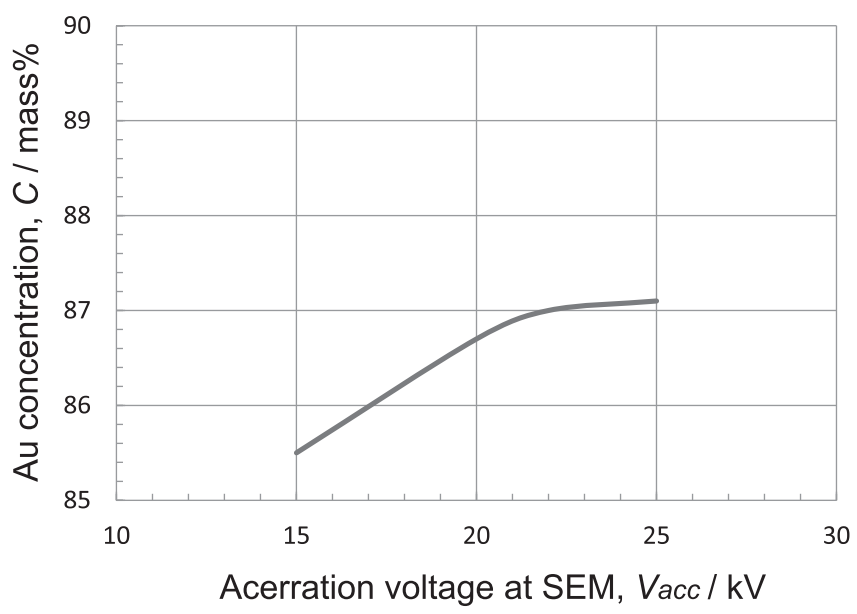

Fig. 9 Relationship between accretion voltage and composition.
(2) $\mathrm{X}$ 線 $\mathrm{CT}$ 像撮影：文字部の $\mathrm{Au}$ 合金の厚さや加工状態 などの文化財資料内部の構造を調べるために, X 線 CT 像を 撮影し，得られた像を解析した結果を Fig. 10 に示す. Fig. 10 (A) は文化財資料に文字面に垂直方向の像で，撮影した装 置や条件は異なるが Fig. 5 と同じ像である.この資料を Fig. $10(\mathrm{~A})$ で示す『一』および『刀』の文字に垂直方向に切る面と 『一』の文字に平行方向に切る面の 2 つの方向から断面構造を 調べた. まず, Fig. 10（B）で示すように，文字部は板厚ぎり ぎりの深さ(約 $1 \mathrm{~mm}$ 程度)まで, 矩形に加工されていること がわかる．上述の SEM-EDS 手法により得られた結果より著 しく厚くなっており，この結果と矛盾しない。この貨幣は鋳 造で溝を制作するのではなく彫金の技法により 1 枚ごとに手 作りで制作されたと考えられる。ささらに，Fig. 10(C)で示す ように, 『一の文字と平行方向に切った面をみるとやはり矩 形に加工されている.この形状は Fig. 10（B）と同様である. このように, X 線 CT 像により加工の状態をみると, 矩形で かつ板厚 $(1.1 \mathrm{~mm})$ ぎりぎりまで加工されており, 高い金属 工芸技法が用いられていることを示している．このような彫 金技法による加工の具体的な手法については不明であり，こ の点を明らかにするために今後の発掘調査などの進展が望ま れる。

\section{3 制作技法の時代的比較}

『一刀』の制作年代に隣接する年代 $\{$ 新より前の西漢 (前漢) と後の東漢 (後漢) と同じ王朝の流れを有する\}に制作された 主な青銅貨と本報告の新時代に制作された文化財資料の組成 および内部構造を比較する。用いた文化財資料は，Fig. 2 で 示すように一刀を中心にその前後の年に首長は異なるが同じ 土地で制作された貨幣である。このうち制作された時代は, Fig. 2 の (A)〜 (E)が西漢, $(\mathrm{F}) \sim(\mathrm{K})$ が新, そして, (L)が東

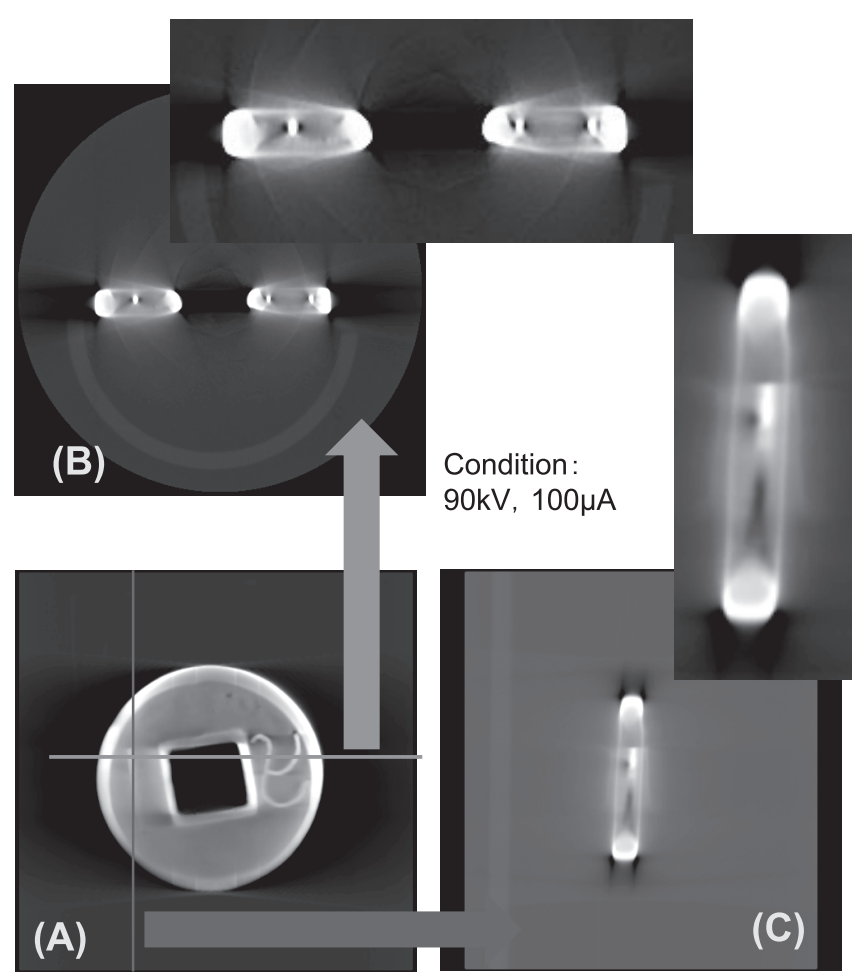

Fig. 10 X-ray CT images of "Ittou" ancient old coin 
漢である。内部構造は X 線透過像から，内部に鋳造鬆等の 存在を調べることにより制作当時の鋳造技術をみていく。こ れにより，西漢から新を経て東漢に至り制作された貨幣を通 して制作当時の製造技術の一端を調べることができる．本 来，このような検討には多数の資料を用いて組成などの平均 值を求めるべきである。しかし，これらが文化財資料である ことから複数の資料を調べることが困難であるため，今回は 単数の資料の調査にとどめ, このような手法による検討の意 義を探ることとした。

\subsection{1 組成による比較}

一刀の制作年代と前後する年代および同一地域で制作され た青銅貨の組成と比較する，上述のように，ここでは比較す る資料が文化財資料であり，用いることができる資料数に限 りがあるので，着眼点を提案するとともに，変化の傾向をみ るのにとどめる. Fig. 2 で示す研究に用いた文化財資料はす べて出土銭である，資料の組成を求めるのにあたり，Fe に ついて $5 \%$ 以下の Fe を含む貨幣は土壤(主に黄土) 起因か, 貨幣の構成成分に起因するかは区別できないので，分析值を そのまま示す。そこで, $\mathrm{Fe}$ を除いて土壤に起因する元素 ( $\mathrm{Si}, \mathrm{Mg}, \mathrm{Ca}, \mathrm{P}$ など) や保存環境に起因する元素 $(\mathrm{Cl}$ と $\mathrm{S}$ ) は除外し， $\mathrm{Cu}, \mathrm{Sn}, \mathrm{Pb}, \mathrm{Fe}$ を中心文化財資料の組成を求 めた，得られた結果を制作年代とともに Table 4 に示す。ま ず， $\mathrm{Pb}$ 濃度に注目すると, 多くの文化財資料は概ね数パー セントから十数パーセントの範囲である. $\mathrm{Pb}$ は溶湯の流れ を制御するなどの作用があるので鋳造においては青銅に添加
されることが多い12,13). また，現代の金属材料の視点からみ ても $\mathrm{Pb}$ 青銅として用いられているが，このときの $\mathrm{Pb}$ は 5〜 20 mass \% 程度含むとされる ${ }^{14)}$. 今回調べた文化財資料の多 くはこの範囲にある。資料の中で，西漢 5 銖銭の一つは $\mathrm{Pb}$ が約 73 mass\%であり，この他に，30 mass\%を超える文化財 資料が $2 つ$ る。この $\mathrm{Pb}$ 濃度が高い資料は, $\mathrm{Cu}-\mathrm{Pb}$ 系の溶 湯を型に流し込むと表面に $\mathrm{Cu}$ とは非固溶の $\mathrm{Pb}$ が析出した ためか，あるいは，貨幣の質を落として $\mathrm{Pb}$ 銭として作られ たことなどが考えられる。また，この $\mathrm{Pb}$ 濃度が高い資料か ら Sn が検出されないのは, Sn を含んでいないか, あるいは 表面の $\mathrm{Pb}$ により $\mathrm{X}$ 線が遮蔽されて検出できないのかもしれ ない.

Sn に着目すると, Sn を含まない資料から, 数 mass\%から 十数 mass\%含む資料までさまざまで, Sn 濃度の分布範囲は 広い. 西漢時代に製造された 8 銖半両は 30 mass\%を超える $\mathrm{Sn}$ を含む。これらの資料は $\mathrm{Sn}$ 濃度が高いか, あるいは溶湯 の凝固時に Snの逆偏析により表面に高濃度の Sn 層が生成 した可能性が考えられる。既報 ${ }^{2}$ の出土資料の和同開珎にお ける組成分析において，土中での腐食により Sn が優先的に 溶出し地金の $\mathrm{Sn}$ 濃度より低下していることと同様のことが 考えられる.

次に, Fe について検討する。 上述のように, Fe が検出さ れるのは，(1)文化財資料起因，(2)資料に付着している黄土の 2 つの起源が考えられる. Fe 濃度は 1 mass\%未満から 20 mass \% 程度まで広く分布している。用いた文化財資料はすべ

Table 4 Composition of metal ancient coins

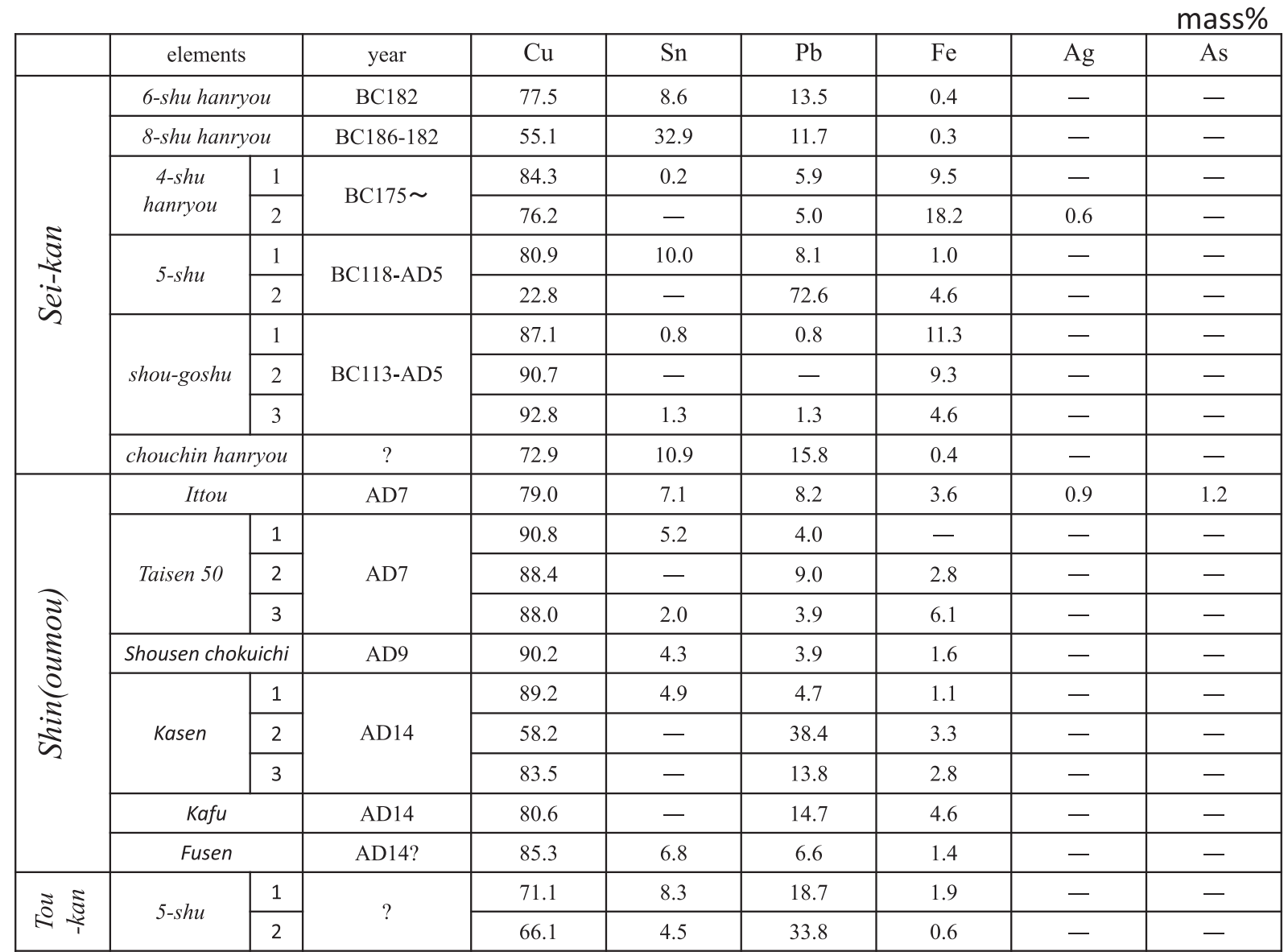


て埋蔵文化財であるが，(2) の壤起因とすると Fe 濃度の変 動は少ないと考えられる。ここで, 制作年代と Fe 濃度との 関係についてみると, 西漢(あるいは前漢)の時代の文化財資 料は 1 mass\%未満から 20 mass\%程度まで大きな変動がみら れる。 これに対して，王莽の新の時代に制作された文化財資 料の $\mathrm{Fe}$ 濃度は 1.1〜 6.1 mass\%程度で変化が西漢の時代に比 べると少ない，さらに，東漢になると資料数は少ないが $\mathrm{Fe}$ 濃度は低くなる。 Fe の組成をみる範囲では 1 mass \%未満の 值もみられることから土壌起因の Fe は僅かで, 文化財資料 起因が大半であるのかもしれない.これは $\mathrm{Cu}$ の原料である 銅鉱石に由来すると考えられ，これは制作当時の銅の精錬技 術水準を示している。この観点から組成をみると, 新から東 漢の時代には製錬技術が向上してくるが，不純物として 1 mass\%程度の Fe が含まれる。

最後に, 文化財資料の主成分組成の時代的な変遷について 概観し, 一刀の組成上の位置付けを検討する. 西漢の時代の 文化財資料のうち半両銭をみると種類や同一資料内でも組成 の変動が大きく, かつ, 一定の傾向はみられない. 特に, 西 漢の建国当初の貨幣は地域の平定に努めた結果, 西漢の前の 時代である秦からの引き継ぎで製造したと伝えられ，西漢の 技術は使われていないと考えられている，ここで，銖は $\mathrm{Cu}$ 濃度に比例した単位である ${ }^{15)}$ 。その後の西漢が発行した五 銖は $\mathrm{Pb}$ の変動が大きいが, その後に発行された小五銖の組 成は比較的揃っている。しかし，五銖と小五銖の組成は異な る. 王莽の新の時代に制作された文化財資料の組成は, $\mathrm{Cu}$
が 80〜90 mass\%, Sn が 5〜 7 mass\%程度, Pb が貨布を除い て 4〜8 mass\%程度と変化が少ない. 西漢の時代の資料と比 べると, やや $\mathrm{Cu}$ 濃度が高い傾向にある，この中で，一刀は $\mathrm{Sn}$ と $\mathrm{Pb}$ の濃度が高い方に分類される. $\mathrm{Pb}$ は新の時代の後 半に向けて高くなる傾向がみられ, $\mathrm{Cu}$ 不足を反映している のかもしれない. また, Fe は 1〜 6 mass\%程度と西漢の時代 に比べて濃度は低く，その範囲も狭い傾向がみられる。この 他に, 一刀からは微量元素として Ag と As が 1 mass\%程度 検出される. 他の資料をみると西漢時代の四銖半両から微量 の $\mathrm{Ag}$ が検出されただけである.これらの元素は銅鉱石の不 純物と考えられ，製錬技術が十分に発達していないことを示 している. 最後に, 東漢において制作された資料は 2 つであ り, 西漢や新の時代のような組成的な特徵は議論できない が, $\mathrm{Cu}$ や $\mathrm{Sn}$ の濃度は西漢の六銖半両銭や提灯半両銭に近 い.また, $\mathrm{Pb}$ や $\mathrm{Fe}$ の濃度はこれらに近く, $\mathrm{Pb}$ 濃度が高く $\mathrm{Fe}$ 濃度は低い。

\subsection{2 内部構造の比較}

本研究で用いた文化財資料は鋳造により制作されているこ とが知られている，その場合，鋳型からの転写性と鋳造鬆の 生成が金属工芸技法的な視点となる，転写性については資料 が埋蔵文化財であることから腐食による劣化と区別が困難で あるので, 本報告では鋳造鬆の生成に着目することとした. そのために, X 線透過像を撮影し, その内部構造を調べた結 果を Fig. 11 に示す. Fig. 11 で示す像は, (A)〜 (D) が西漢時 代に制作された資料, (E)〜 (H) が新, そして, (G) が東漢

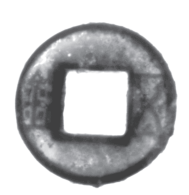

(A) Goshu
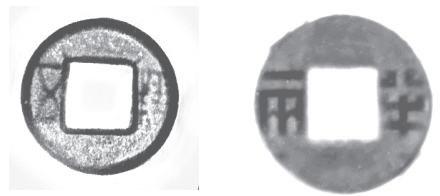

(B) Yonshu

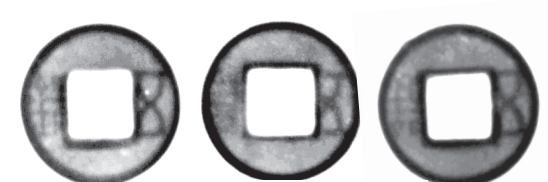

(C) Shou goshu

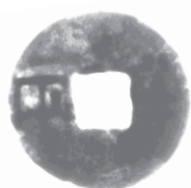

(D) Rokushu
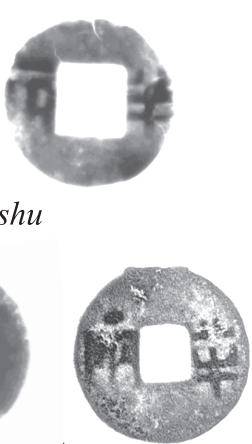

(E) Hasshu

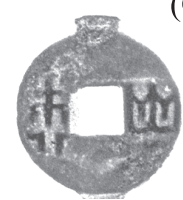

(F) Chouchin

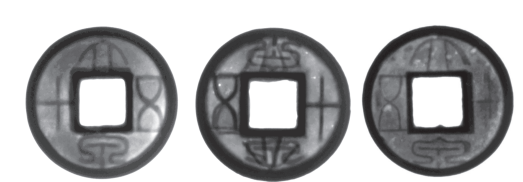

(I) Taisen gojyuu

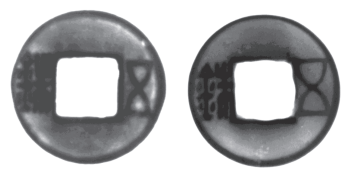

(K) Gokan-Goshu
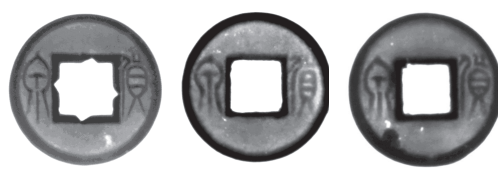

(H) Kasen

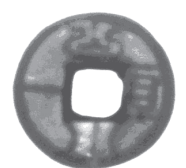

(J) Shousenchokuichi

Fig. 11 X-ray transmittance images of ancient Kan's coins. ( 150 kV, 3 mA, $10 \mathrm{~s})$ 
時代である。まず，西漢時代に制作された資料についてみて いく. Fig. 11(A) で示す 5 銖半両銭には全面に多くの鋳造鬆 が観察される。同 (B)の 4 銖半両銭のうち右側の文化財資料 の上部に亀裂がみられ，下部には鋳造鬆が存在している。左 側の資料では亀裂も鬆もみられない。ささらに, 同 $(\mathrm{C})$ の小 5 銖は小型の貨幣ではあるが，3枚ともに鬆が生成している. 同 (D)の 6 銖は左側の文字の部分に鬆が生成していることが わかる. 以上の検討から, 西漢時代の資料の大半に鋳造鬆が 生じている，新の時代および東漢の資料をみると，いずれの 資料ともに鋳造鬆が生成している.

青銅成分以外の構成元素のうち鋳造において融点の低下に より溶湯の流れを制御し転写性などに関係することが知られ ている $\mathrm{Pb}$ と $\mathrm{Sn}$ に着目する. $\mathrm{Pb}$ は含有濃度により, (1) $10 \%$ を超す濃度である資料, (2)数\%から 10 mass \%未満の資料, そして, (3) 1 mass\%以下の資料の 3 つのグループに大別され る. 現代の鉛青銅では 5〜20 mass\%の Pb を含有してい $3^{14)}$. 西漢 5 銖の 1 つと新の貨銭の 1 つが該当しないが, 概ねこの範囲に入っている，詳細にみていくと，6 銖および 8 銖半両銭ならびに提灯半両は(1)に，4 銖半両および 5 銖は (2)に, そして, 小 5 銖は(3)に分類される. 新の時代は貨泉の 2 枚と貨布が(1)に属し，その他の資料は(2)に属する．東漢の 資料は少ないがいずれも(1)に属する。（3)の $\mathrm{Pb}$ 濃度における 溶湯の流れに及ぼす影響の詳細については不明であるが, $\mathrm{Pb}$ 濃度に依存せず鋳造鬆が生成していることがわかる. $\mathrm{Sn}$ については，西漢の 8 銖を除くと，検出限界以下の文化財資 料から 10 mass\%程度の資料まで分布している。この濃度範 囲では溶湯の流れは 2 mass\%付近が極小になることが知られ ている ${ }^{16)}$ 。この点を考慮しても溶湯の流れに影響がみられ ることは少ないと推定され, 鬆の生成に資料の組成の関与は 考え難い.

以上のことから, $\mathrm{Pb}$ や $\mathrm{Sn}$ 濃度に依存して溶湯の流れの影 響による鋳造鬆の生成は特に考えにくいと言える。さらに, 文化財資料の組成および内部構造の両面からの検討による と，西漢が制作した文化財資料から新の時代以降の時代では 貨幣の製造技術が安定する傾向が見られる。このことから， 今後, さらに多くの文化財資料について同様の観点から検討 していき，より詳細な流れを調べていくことが可能である.

\section{4. ま と め}

中国，新の時代に制作されたと伝えられる貨幣である『一 刀』を文化財資料として取り上げ，材料学的視点から金属工 芸技法を調べ，以下の結果を得た。

（1）赤外線像から資料表面には鋳造時に生成したとみら れる凹凸が存在する。X 線透過像から資料中に鋳造鬆がみら
れる.制作当時の鋳造技術の一端を示している.

（2）資料の組成は $\mathrm{Cu}, \mathrm{Sn}, \mathrm{Pb}$ を主成分とし，X 線回折 から $\mathrm{Cu}^{-} \mathrm{Sn}$ 系金属間化合物が検出される青銅である. 表面 には黄土が付着しており，また，SEM-EDS 分析から $\mathrm{Si}$, $\mathrm{Al}, \mathrm{Fe}$ が検出され, 出土品であることを示している.

（3）『一刀』の文字は 10 mass \% $\mathrm{Cu}-\mathrm{Au}$ 合金でつくられて おり，表面には多くの傷がみられる，X線 CT 像から，この 文字は資料の板厚ぎりぎりまで彫金技法を用いて加工した後 に，この合金を嵌め込む象嵌の技法が用いられている.

（4）『一刀』が制作された時代より前の西漢および新，そ して東漢の文化財資料の組成を $\mathrm{Cu}, \mathrm{Sn}, \mathrm{Pb}, \mathrm{Fe}$ を中心に調 べたところ，西漢が制作した資料より新以降の資料の組成が 安定する傾向がみられる．また，時代が下るにつれて Fe の 含有量が低下し，製(精)錬技術が向上する傾向が見られた. しかし，資料中には制作年代にかかわらず鋳造鬆がみられ， それは資料の $\mathrm{Sn}$ や $\mathrm{Pb}$ の組成に依存していない.

本研究を進めるのにあたり，X線透過像撮影にご協力いた だいた東京藝術大学木島隆康教授に感謝いたします。また,

(株)リガクの澤野成民氏ならびに山田鮎太氏には文化財資料 の X 線 CT 像を撮影していただいた。ここに記して深謝す る.

文献

1) T. Ashida: Das geldwesen Japans: Entwicklung und Vergleichung mit demjenigen in europäischen Ländern/vorgelegt von Teruo Ashida (in German), (Gedruckt bei Benedikt Hilt publication, Berlin 1912).

2) F. Kirino and M. Kitada: J. Japan Inst. Met. Mater. 79 (2015) 57-63.

3) F. Kirino: Bul. the Faculty Fine Arts, Tokyo Univ. the Arts 52 (2014) pp. 5-16.

4) F. Kirino, I. Iino, S. Tabuchi and M. Kitada: Bul. the Faculty Fine Arts, Tokyo Univ. the Arts 53 (2015) pp. 5-22.

5) F. Kirino, N. Ohono, S. Taguchi, A. Nezu and R. Yokoyama: J. Japan Inst. Met. Mater. 81 (2017) 101-108.

6) F. Kirino, N. Ohono, S. Taguchi, A. Nezu and R. Yokoyama: Annual Spring meeting $\left(155^{\text {th }}\right)$ of $\operatorname{JIM}(2014)$.

7) K. Kurata and M. Nakano: Nihon-no-bijyutsu 39 Kinkou (in Japanese), (Shougakukan, Tokyo, 1974).

8) T. Miyazawa: Chuugoku-dousen-no-sekai (in Japanese), (Shibunkakushuppan, Kyoto, 2007)

9) S. Katou: Chuugoku-kaheishi-kenkyuu (in Japanese), (Touyoubunko, Tokyo, 1991).

10) K. Yamada: Kaheino-chuugoku-kodaishi, Asahi-sensho (in Japanese), (Asahi Shimbun Publications Inc., Tokyo, 2000).

11) M. Hansen: Constitution of binary alloys, (McGraw-Hill Inc., New York, 1958) pp. 198-203.

12) A. Kamio, M. Aoki and S. Oya: IMONO 40 (1968) 827-834.

13) A. Kita, Y. Koguchi, Y. Sakata, R, Yoshiyuki, M. Yokota, T. Kobori and H. Mifune: Bull. Takaoka National College 40 (2003) 115-131.

14) The Japan Institute of Metals and Materials: Chuuzougyouko (in Japanese), (Maruzen, Tokyo, 1999) p. 253.

15) K. Koizumi: Rekishi-nonakano-tani, (Sougoukagakushuppan, Tokyo, 1974) p. 254

16) The Japan Institute of Metals and Materials: Chuuzougyouko (in Japanese), (Maruzen, Tokyo, 1999) pp. 247-252. 